\title{
Exploring supply chain business bullying of small and medium-sized business suppliers by dominant buyers in the apparel retail sector in Gauteng
}

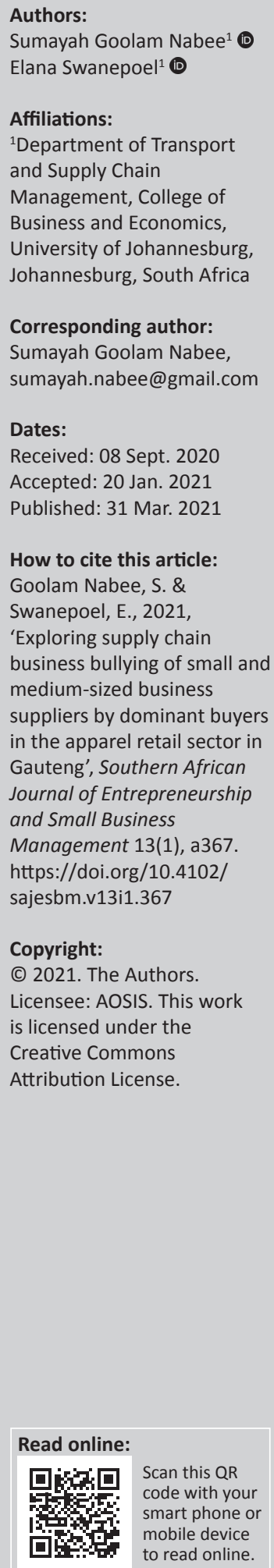

Background: Issues relating to dominant behaviour and bullying practices in supply chains are mostly not reported. Some evidence exists of unfair business practices in the apparel retail sector, but the extent and nature of such practices in South Africa, as well as the business implications for small and medium-sized enterprises (SMEs), have not been researched. The reason could be the sensitive nature of these issues and possible adverse implications for the SMEs supplying apparel to the retailers in Gauteng.

Aim: The primary research objective is to determine the incidence and type of supply chain dominance experienced by SMEs in the retail apparel sector in Gauteng, as well as the business implications of such dominant behaviour and how SMEs cope with it.

Setting: The setting for this study was the business premises of SME apparel suppliers in Gauteng.

Methods: Qualitative semi-structured in-depth interviews were conducted with seven SMEs that were apparel suppliers to the large retailers in Gauteng, to obtain the supplier perspective.

Results: Six of the seven SMEs had experienced some form of bullying behaviour by large retailers in the apparel sector, such as late payments and long payment terms. For some of these SMEs, it had serious financial implications. Meaningful insight is provided into this supplier-buyer relationship between SMEs and large retailers in the apparel sector in Gauteng.

Conclusion: This is the first study in South Africa investigating supply chain dominance, in particular supply chain bullying of SME suppliers through unfair business practices by dominant buyers in the apparel sector.

Keywords: bullying; collaboration; dominant behaviour; supply chain dominance; SMEs; unfair business practices.

\section{Introduction}

A supply chain is a network made up of several complex activities that involve multiple key members, such as buyers, suppliers, service providers and end-consumers (Arshinder, Kanda \& Deshmukh 2011). To ensure the success of the supply chain, a collaboration between these members, especially between buyers and sellers, is emphasised (Ryu, Soh \& Koo 2009; Vlachos \& Bourlakis 2006). Supply chain management extends beyond the design and management of various logistics activities and principally must include the management of buyer-supplier relationships to ensure its success (Ambrose, Marshall \& Lynch 2010).

The collaborative nature of supply chain relationships is founded on 'trust, commitment, and cooperation' as well as the 'acceptance and understanding of mutual dependence' (Noémi 2012:131). Supply chain member relationships that lack the balance of dependency and interdependency cause power variations, eventually contributing and leading to unfair business practices (Barber 2011). With a focus on the buyer-supplier relationship, it is observed that contract problems, changes to contracts, 'unfair contracts', interpersonal issues and questions of ethical behaviour are often deemed unfair business practices (Rogers \& Fells 2017).

These unfair business practices are a catalyst for supply chain dominance, which has previously been explored under different terms such as 'supply chain power' (Barber 2011; Hingley, Lindgreen \& Grant 2015; Rahaman, Rau \& Zaman 2020), 'power regimes' (Cox 2004; Cox et al. 
2004; Lapko \& Trucco 2018), 'channel dominance' (Xue, Caliskan Demirag \& Niu 2014), 'relative power' (Chakraborty et al. 2018), 'asymmetrical relationships' (Talay, Oxborrow \& Brindley 2020), 'power-driven relationships' (Benton \& Maloni 2005) and 'dominant player behaviour' (Li et al. 2010).

Cox (2004) addressed dominant behaviour in the supply chain as both the power and appropriateness in a buyersupplier relationship. For a buyer, appropriateness depends on the power and leverage circumstance that they find themselves in' (Cox 2004:346). Xue et al. (2014:132) expressed power as an ability, where 'the dominant party dictates certain decisions of the weaker party'. Barber (2011:167) defined dominance in supply chains as 'the extent of influence one participant in the chain has over one or more participants'. In a definition similar to Barber (2011), Durocher-Yvon et al. (2019) suggested that the influence of one participant on another can be either positive or negative.

The retail apparel sector is characterised by powerful retail buyers and small suppliers (Talay et al. 2020). In their annual performance plan, the Department of Small Business Development in South Africa expressed the concerns of its members over big businesses bullying small businesses (Parliamentary Committee Group 2019). In 2017, the Competition Commission investigated the four big supermarkets - Pick n Pay, Shoprite Checkers, Woolworths and Spar - in the South African retail grocery market and found evidence of unfair business practices towards small and medium-sized suppliers (Broembsen 2017). Some of these retailers also sell apparel. The South African clothing industry recorded an annual production decline of $4.9 \%$ in 2018 as low-cost Asian suppliers continued to flood the market (Research and Markets 2019). The vulnerability of the local market is therefore prone to asymmetrical relationships and relative buyer power. The objective of this research is therefore to explore if small and medium-sized Gautengbased suppliers in the South African apparel sector experience supply chain dominance by large retail buyers.

\section{Literature review}

\section{Supply chain power relationships}

In competitive industries such as apparel retail, it is common practice for buyer-supplier relationships 'to be viewed as win-lose situations', even when the collaboration between buyers and suppliers is crucial to survival in changing business environments (Munyimi \& Chari 2018:1). Cox (2004) maintains that even when given win-win partnering or win-lose outcomes, there is not only one way to manage the buyer-supplier relationship.

Supply chain relationships are driven by collaboration through high levels of information sharing (Emmett \& Crocker 2006). In this context, three types of collaboration can be identified: Type I are collaborative transaction management relationships which focus on standard information exchanges. Type II are collaborative event management relationships that pursue 'standardised decision-making' and 'exchanges of non-transactional information'. Type III are collaborative process management relationships that require 'building trust, setting joint business goals and designing interenterprise processes' (Whipple Judith \& Russell 2007:184).

For small and medium-sized enterprises (SMEs), strategic collaboration and information sharing in the supply chain are essential elements of competitive advantage (Kumar, Singh \& Shankar 2016). The assumption, however, that collaboration is voluntary and results in equal power in the supply chain is unfounded (Kampstra, Ashayeri \& Gattorna 2006).

Kampstra et al. (2006) further outline that powerful retailers such as Walmart often dictate how collaboration is practiced in a supply chain. Financial actions such as pay to stay, longterm payments, late payment, prompt payment discounts and respective discounting are often used to exert dominance (Durocher-Yvon et al. 2019; The Federation of Small Businesses 2018). Barber (2011) identifies five types of supply chain dominance: manufacturer-centric dominance, retailcentric dominance, supplier-centric dominance, distributorcentric dominance and reverse dominance, of which retailcentric dominance is discussed in more detail.

A power shift downstream in the supply chain, where customer information is more readily available, has resulted in retail-centric dominance by powerful retailers such as Walmart, Amazon.com and Costco (Defee, Randall \& Gibson 2009; Dekimpe 2020). The presence of a dominant retailer in a supply chain has many benefits, such as lower total transaction costs (Barber 2011), facilitating retail segmentation into discount and speciality shops (Dukes, Geylani \& Srinivasan 2009), lower retail prices for consumers (Chen 2003) and the ability to lower wholesale prices when the dominant retailer has a large market share (Chen \& Zhuang 2011). Dominant retailers tend to focus their efforts on fast-moving consumer goods (FMCG) where product design is simple, high volumes are manufactured, lead times are short and manufacturing processes are reduced (Bala \& Kumar 2011).

The relative downstream position of the retailer in the supply chain affords the retailer market size, market sensitivity and retail-processing cost information, which can be used to dominate suppliers as part of achieving their strategic goals (Wang, Lau \& Lau 2008).

Habib, Bastl and Pilbeam (2015), citing Cox (1999) and Cox (2001), view the dependent supplier as a construct of dominant buyers, although a dominant position by a retail buyer is not always viewed as negative. Seppenwoolde (2019) found that even where supplier squeeze occurs, a supplier may be happy with the relationship if it offers growth opportunities. Furthermore, the need for long-term cooperation can lead to more fairness by dominant players (Jarratt \& Morrison 2003). Small and medium-sized suppliers can balance out the actions of dominant buyers by customer prioritisation, presenting competitive advantage opportunities and developing specialised knowledge (Talay et al. 2020). 
Both buyers and suppliers have sufficient reason for wanting to occupy positions of power. Collaboration is a means of managing the relationship even if one party will always exert more influence than the other in the supply chain. It is therefore essential to understand the nature of the relationship between SMEs and large retailers when the retailer holds the dominant position.

\section{Relationships between small and medium-sized suppliers and large retailers}

Small and medium-sized enterprises are key economic contributors to aiding innovation and job creation (Kaira \& Rześny Cieplińska 2019). In South Africa, SMEs range from formally registered to informal and non-VAT registered organisations (Bureau for Economic Research 2016). In 2016, the number of formal SMEs in South Africa was 68494 and 17397, respectively (Small Business Institute 2018). Furthermore, SMEs employ $47 \%$ of the South African workforce and contribute a respectable $20 \%$ to the country's gross domestic product (Liedtke 2019).

For purposes of this study, SMEs are classified by the South African National Small Business Amendment Act (26 of 2003) according to the number of employees and the annual revenue of the company (Department of Small Business Development 2019). The Act states that medium-sized businesses in wholesale trade may not exceed 250 employees or a turnover of more than R220 million per annum (Small Business Institute 2019). Small enterprises are defined as having a maximum of 50 employees and in the wholesale trade a maximum turnover of R80m per annum (Department of Small Business Development 2019).

It is commonplace for small and medium-sized suppliers to specialise in specific product lines or supply retailer brands exclusively (Delberghe 2016). With strict competition from major brand manufacturers, market entry for many SMEs is made easier by concentrating on retailer brands (Delberghe 2016). Business-to-business SMEs often overlook the importance of branding and without a powerful own brand, they compete for retail shelf-space (Lin et al. 2019; Von Broembsen 2017). This dependence of SMEs on retailer buyers has therefore increased the relative power of retailers in the supply chain.

As such, SMEs are subjected to control, quality testing and product and packaging demands by retailer buyers (Pepe, Musso \& Risso 2010). Other dominant behaviours enforced by retailers include providing cash discounts to themselves, allowing long credit periods (Tsao 2011) and setting of wholesale prices (Jerath, Hoch \& Zhang 2007).

Popović, Mihailović and Simonovic (2018) examined unfair trading practices in the food industry and found that retailers abuse their bargaining power by transferring costs to suppliers, asking suppliers for favours without similar reciprocation, making one-sided changes to a contract, retrospective changes to contracts, unfair termination of contracts and unjustified threats to terminate contracts. Schleper, Blome and Wuttke (2017:97) extend the retailers' dominant power to include 'pressuring suppliers for price reductions, non-cost related payments or discounts, extended payment terms, warranty periods and questionable appropriation of innovations and intellectual property'.

\section{Examples of buyer-dominant behaviour in supply chains}

The concept of power in the supply chain was first discussed from the perspective of inter-firm dominance where five power bases - legitimate, reward, expert, referent and coercive - were identified (Raven \& French 1958). In the last few years, buyer dominance was explored in various industries, namely automotive (Khan 2018; Skeete 2019; Wilhelm \& Sydow 2018), aviation (He et al. 2014; Schleper et al. 2017; Tang, Zimmerman \& Nelson 2009), consumer electronics (Guo et al. 2012; Schleper et al. 2017) and FMCG and retail (Digal 2015; Hingley 2005; Knox 2016; Palpacuer, Gibbon \& Thomsen 2005).

In the automotive industry, the concept of open-book pricing by original equipment manufacturers (OEMs) has been viewed as dominant behaviour by suppliers (Skeete 2019). To counteract competition from China, General Motors threatened to outsource production overseas if suppliers did not cut costs (Khan 2018).

Volkswagen (VW) is known, after the start of production, to fuel competition by getting quotes from other suppliers (Wilhelm \& Sydow 2018). As dominant manufacturers in the aviation industry, both Boeing and Airbus demand lower costs and greater outputs from their suppliers (He et al. 2014; Schleper et al. 2017). In the supply chain of the Boeing 787 aircraft, the financial risk of development was passed on to their suppliers (Tang et al. 2009).

As the consumer electronic market grows, incidences of domination by powerful electronic brands are more prevalent. Schleper et al. (2017) outline Apple's supplier squeezing strategies where suppliers risk losing business if they produce non-Apple-related products. Although not a direct result of dominant behaviour, the high-speed production demands of Apple, Dell and Hewlett-Packard have led to many suicides at Chinese electronics supplier Foxconn Technology Group (Guo et al. 2012).

Dominant behaviour by retail buyers is widespread (Durocher-Yvon et al. 2019; Schleper et al. 2017). As one of the largest retailers in the world, Amazon has repeatedly dominated supplier efforts by discouraging customers from buying from a certain supplier (Kirkwood 2014) and by infringing on patents, demonstrating unfairness in competition, interfering with contracts and false advertising (Greenfield 2011). PopSockets, a phone accessory supplier accused Amazon of forcing price reductions on their products or risk being replaced (Young 2020). Similarly, Walmart has been accused of forcing contracts, price-fixing, and 
cost-sharing on its suppliers (Cambero 2020; Layne 2015). To meet financial targets, the United Kingdom's largest grocer Tesco, often underpaid or late-paid suppliers (Ram 2016).

Spanish fashion retailer Zara is an intellectual property thief, according to independent artists and designers who have not been paid for their designs but found copy-cat designs in Zara clothing and accessory ranges (Mallory Schlossberg 2016). British retailers fair no better; Marks \& Spencer has asked its suppliers to contribute millions of pounds for store improvements and advertising (Gordon 2011), whilst Laura Ashley imposed a 10\% discount on suppliers (Neville 2013). Amidst the novel Coronavirus Disease (2019-nCoV) pandemic, Australian retailers Kmart and Mosaic Brands informed suppliers that they would not meet financial commitments, asked for discounts and pushed back orders whilst still demanding short order lead times (Black 2020).

\section{Competitiveness in the retail apparel industry}

Globally, the apparel retail industry is valued at $\$ 1467.7$ billion with the South African market valued at $\$ 9813.5 \mathrm{~m}$ (Marketline 2020a, 2020b). The market is defined by high sales of womenswear, increased online shopping and more awareness of sustainability by the industry (Bertram \& Chi 2018).

The industry is segmented by price controls led by large retailers, brand control by major companies and specialised retailers, and the fashion-sensitive segment which focuses on sustainability (Manuel Xavier et al. 2015). Although offering low barriers to entry, apparel retailers operate in a highly competitive and highly saturated market where buyers demand low prices whilst growth in sales are marginal (Watchravesringkan et al. 2010).

The competitive landscape today is fuelled by direct purchases from manufacturers, pure online stores, global online shopping, custom-made clothing and second-hand purchases (Amed et al. 2019). Mergers and acquisitions are common and low pricing or increased sales are insufficient to remain competitive (Klemz et al. 2008). Maintaining and increasing competitiveness can be successfully achieved through offering a unique brand experience, store experience and customer service experience (McColl \& Moore 2013).

The South African market trends are driven by strong growth in mobile e-commerce which has seen retailers adopting a multi-channel approach to remain competitive (Euromonitor International 2020). Other strategies adopted include increasing sales by diversifying product offerings, aggressive pricing methods and complimentary in-store services, such as purchasing of bus tickets or payment of utility bills (Euromonitor International 2020). Steinhoff (Pep stores) and Mr Price, the two largest players in the market, continue to attract budget-conscious customers through their value for money and mass-market strategies (Marketline 2020a).

\section{Major players in the South African apparel retail sector}

The South African retail apparel sector is characterised by four major local players of which Steinhoff International Holdings NV (Steinhoff International) commands the largest market share with the Pep, Ackermans, and Dunns brands (Marketline 2020a). The Mr Price Group Ltd (Mr Price) considers itself a fashion-value retailer and is the secondlargest player in the market. These two are followed by Truworths International Limited (Truworths International) and Edcon Holdings (Proprietary) Ltd. (Edcon) (Marketline 2020a). The market is further fragmented by other global fashion retailers from Spain, the United Kingdom and Australia (Douglas 2016).

Suppliers to the market are made up of both clothing manufacturers and wholesalers that are locally and internationally based (Kew 2020). The labour-intensive nature of the industry favours low-wage regions, which together with the drive for more secure supply chains and the ability to cope with changes in demand have all decreased supplier power and kept retailers' switching costs moderate (Marketline 2020a). Driven by the need to secure supply chains and the COVID-19 pandemic, large local retailers are reducing their dependency on Chinese suppliers and are increasingly sourcing from local suppliers (Kew 2020).

\section{Research problem}

Evidence has emerged of unfair business practices in the South African retail sector, but the type and extent of such practices, or their implications for SMEs, have not been researched (Durocher-Yvon et al. 2019; Von Broembsen 2017). A gap therefore exists in the body of knowledge pertaining to such unfair business practices, in particular in the apparel retail supply chain in South Africa.

\section{Research questions}

The research questions that followed from the literature review and guided the study are listed next:

- To what extent does supply chain dominance occur in the apparel industry with SME suppliers supplying the large retail industry in Gauteng?

- What forms of supply chain dominance are experienced by SME apparel suppliers and what are the business implications for them?

- How do SME suppliers in the apparel sector respond or counteract the effects of dominant behaviours from buyers?

\section{Research strategy Explanation of methodology}

'Qualitative research is an approach for exploring and understanding the meaning individuals ascribe to a social or human problem' (Creswell 2014:4). Owing to the fact that the 
concept 'supply chain dominance' could be foreign to the potential participants, it was necessary to conduct qualitative in-depth interviews to explain the concept and to explore and probe its extent, nature of occurrence and business implications.

Qualitative in-depth interviews were conducted with the suppliers of apparel to the retail industry to collect primary data using a semi-structured questionnaire. The inclusion criteria for the population were any SMEs supplying apparel to the retail sector in Gauteng. There are numerous importers and distributors in South Africa who supply the major retailers (Flanders Investment \& Trade 2016). A database of these SMEs does not exist and was therefore created. All those for whom contact details could be sourced from the internet, were included in the database.

\section{Data collection}

Over a period of 3 months, 87 phone calls were made to those SMEs for whom telephone numbers were obtained. Although emails were sent frequently (three to four emails each) to secure appointments, only eight responded. According to Saunders, Lewis and Thornhill (2019:317), for a homogenous group the target can be between 4 and 12, and for a heterogenous group between 12 and 30. Although the apparel suppliers all supply to the retail industry, and in that respect were homogenous, they varied in size and were considered heterogenous. For this reason, the target was 12-30 participants. Even though the focus of the research was explained at the time of making the appointment, five potential participants, who had initially agreed to an interview, chose to withdraw when the interview started. They stated that the risk, of retailers finding out they had participated in the research, was too high. Another reason given during a telephonic interview by a potential respondent was:

'The market is extremely saturated, and the risk outweighs the potential return for me, therefore I would like to refuse the interview for this research.' (Non-participant 1, business owner, June 2018)

A non-probability snowballing sampling strategy was applied, relying on the recommendations from one volunteer SME. Snowball sampling is used when potential participants are hard to find (Saunders et al. 2019). Snowballing as a sampling strategy was unsuccessful as many of the participants were not willing to share contact details of other possible participants. The main reason was that potential participants expressed a fear of being found out by the larger retailers. Even though they were ensured of strict confidentiality, the risk was too high for these potential participants. A new sampling strategy was devised, by cold calling and reaching out to members outside the industry to provide possible contact details of members in the SME apparel supply sector in Gauteng. Eventually, seven interviews were secured.

\section{Characteristics and appropriateness of the sample}

Prior to continuing with interviews, it was necessary to determine the relevance of the participants. Six of the seven businesses had been established in the apparel industry for more than 10 years, with one being established for 2 years. The length of time that businesses had been established varied between 2 and 60 years. Four participants had even worked in the apparel industry prior to starting their own business, whilst a further two participants had always worked for the family apparel business. It can be deemed that they had the relevant experience to comment on supply chain dominance in the apparel industry in Gauteng.

All seven participants were SMEs based in Gauteng and sold apparel to major retailers in South Africa. Two of the SMEs stated that they had international suppliers but did not supply their own products abroad. According to the National Small Business Amendment Act's (26 of 2003) classification of SMEs by number of employees, of the seven participating SMEs, two were medium-sized, two small, one very small and two were micro enterprises (Figure 1). It is not possible to provide more detailed information about each supplier as this would risk the identification of the supplier.

The National Small Business Amendment Act (26 of 2003) also classifies SMEs by annual turnover.

According to the annual turnover classification, of the seven SMEs, two are medium-sized, three are small, one is very small and one is a micro enterprise (Figure 2). All seven participants are classified as SMEs and complied with the inclusive criteria.

\section{Data collection instrument}

Thedatacollectioninstrument, asemi-structured questionnaire, was self-developed from studying literature on supply chain dominance, incorporating the different forms of supply chain dominance in the questionnaire whilst allowing for participants to add other forms of supply chain dominance experienced. Being a semi-structured questionnaire, it contained quantitative list questions and two Likert-scale question, to guide the probing questions that followed each. The questionnaire has 18 questions divided into four sections:

- Section A: Biographic and corporate data (five questions).

- Section B: The extent of dominant behaviour on SMEs in the apparel retail supply chain in Gauteng (five questions).

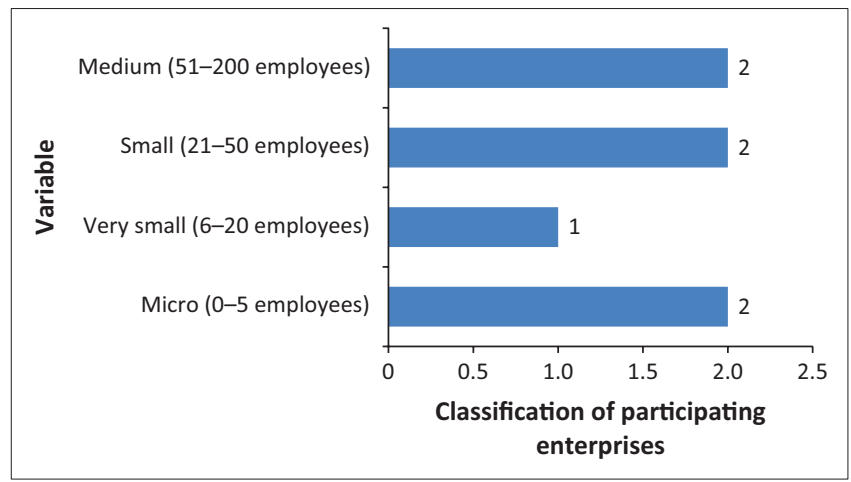

FIGURE 1: Classification of participating enterprises by number of employees. 


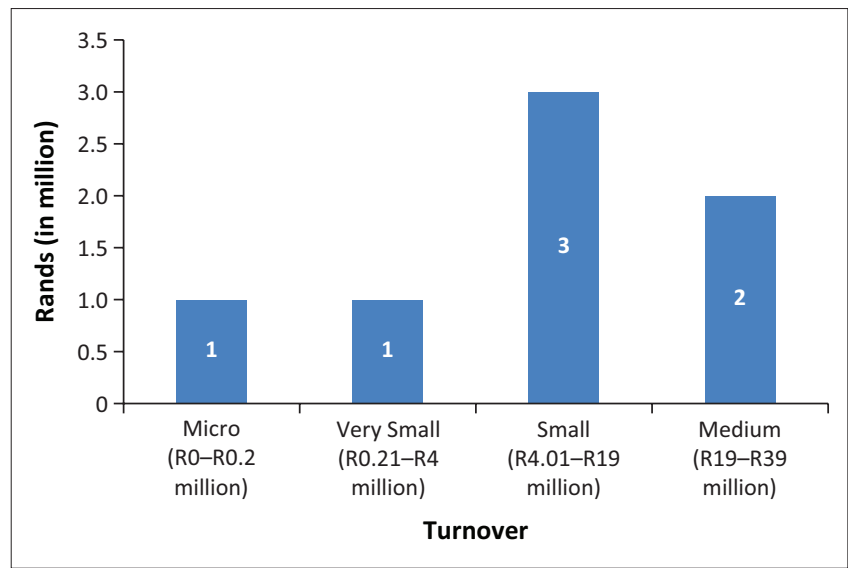

FIGURE 2: Annual turnover of companies interviewed.

The following were addressed - pay to stay; long payment terms; late payment; discounts for prompt payment; and retrospective discounts.

- Section C: Identifying which members in the retail apparel sector supply chain in Gauteng display dominant behaviours as experienced by SMEs (four questions).

- Section D: Identifying the methods of dominance used by the members of the retail apparel supply chain in Gauteng as experienced by SMEs (four questions).

\section{Additionally:}

- Some of the questions had listed options from which a participant could choose. Through probing, it was possible to expand the lists for some questions.

- The questionnaire was approved by the departmental Ethics Clearance Committee.

It was critical to establish a relationship of trust, so that the participants trusted that their information would not reveal their identity. For this reason, pseudonyms are used for the large retailers.

Trustworthiness in qualitative research includes dependability, credibility, transferability and authenticity (Saunders et al. 2019:217). By recording and transcribing the interviews, dependability and credibility are enhanced. As only seven participants were interviewed, the results are not transferable as the sample size is too small. By strictly adhering to the answers and comments of the participants, authenticity is ensured.

The face-to-face in-depth interviews were recorded and transcribed into an MS Word document.

\section{Data analysis}

The seven transcribed interviews, which included verbatim comments, were analysed using thematic analysis, guided by the 18 questions. No coding was required. The themes were contained in the questions and were decided upon during the design of the semi-structured questionnaire. From the existing literature, in particular the study of Durocher-Yvon et al. (2019), it was possible to identify the typical supply chain dominance practices, namely long payment terms, late payments, contractual pressures, pay to stay, discounts for prompt payment and retrospective discounts. By including these in the questionnaire, it was possible to deductively determine the extent, type of occurrence and business implications of supply chain dominance amongst the participants and to compare it with existing knowledge and theory.

\section{Ethical considerations}

Ethical clearance to conduct this study was obtained from the Department of Transport and Supply Chain Management Ethics Committee, College of Business and Economics, University of Johannesburg (Ethical clearance number: 2018 TSCM-014HN).

\section{Results}

\section{Understanding the concept of dominant behaviour}

At the outset of the research which focuses on a topic with which participants may not be familiar, it is essential to determine their understanding of the concept to ensure that the responses are within an informed context. Five out of the seven participants interviewed understood what dominant behaviour was and could provide examples of dominant behaviour practices. Some examples that were provided include the extension of payment terms: 'take it or leave it' meetings where no room for negotiation is awarded, over ordering by retailers who returned goods after 60 days and concerns that 'retailers dictate all terms'. For the two participants who needed clarification, a definition was given and explained with some practical examples.

Interestingly, one participant whilst familiar with dominant behaviour did not consider or interpret their own similar experiences as dominant behaviour.

\section{Evidence of dominant behaviour in business practices}

As shown in Figure 3, for the seven participants that experienced dominant behaviour, late payment was the most common. A participant stated:

'The 90-day late payment forced me to write off the transaction as a bad debt. The cost of this particular transaction was over R500 000 and being a small business, it placed me in financial trouble. It affected my cash flow.' (Participant 2, medium-sized business owner, July 2018)

The second highest dominant practice identified by five participants was long payment terms. This included extended payment terms which participants stated as common practice when dealing with retailers. A participant explained:

'When the payment terms were extended to 120 days, we struggled to stay afloat as we could not pay our own suppliers and did not have the same power of negotiation with our suppliers.' (Participant 3, small business owner, July 2018) 


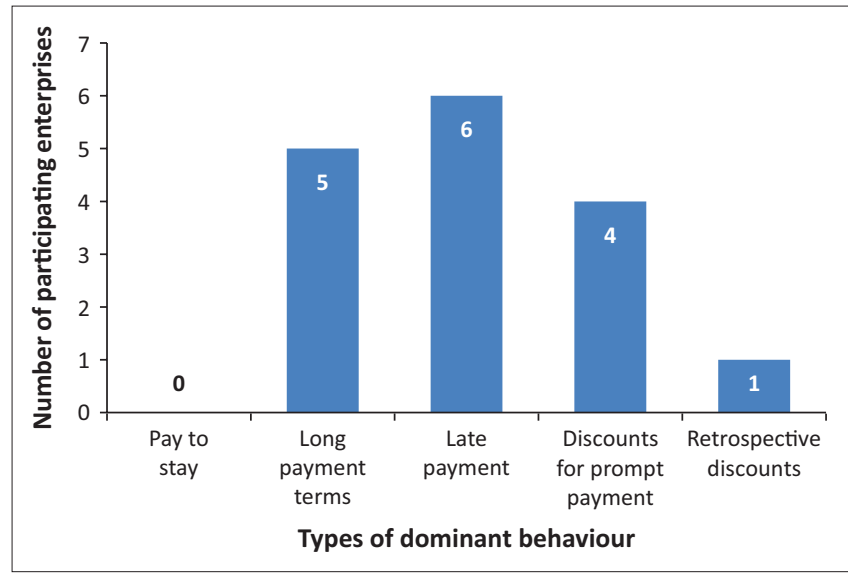

FIGURE 3: Dominant behaviour and the manner in which it occurred.

A further two dominant behaviours experienced were the discount for prompt payments (four participants) and retrospective discounts (one participant). These two forms of dominant behaviour do not seem to have the same financial impact on the business as the first two. The only dominant practice that was not identified by the participants was pay to stay. As the two most prominent dominant behaviour practices are based on the buyer paying the supplier, it is evident that this could have a serious effect on the SMEs long-term sustainability and business survival.

\section{Frequency of dominant practices}

The frequency of dominant practices can be linked to the seriousness of its business implications for SMEs.

The more prevalent dominant practices are, the more likely they are to have a serious impact on SMEs. All seven participants had experienced some form of dominant behaviour in their business. It can be deduced that having identified the forms of dominant behaviour, participants were able to recognise the occurrence of these practices in their business even if prior to the interview they were not aware of such practices occurring (Figure 4). Four of the participants had experienced some form of dominant behaviour 'very often' (eight or more times per annum), whilst another had experienced it 'often' (six to eight times per annum).

The remaining two participants experienced it seldom (three to five times per annum) and rarely (one to two times per annum).

\section{Dominant behaviours in contractual agreements and their effect}

Five of the seven participants indicated that dominant behaviour could be found in contracts with major retailers. Participants were probed to identify dominant practices stipulated in the contract. Participants cited the following examples:

'Penalties for late delivery where the shipment was delayed owing to lack of berthing space in the port of Durban ... [and]

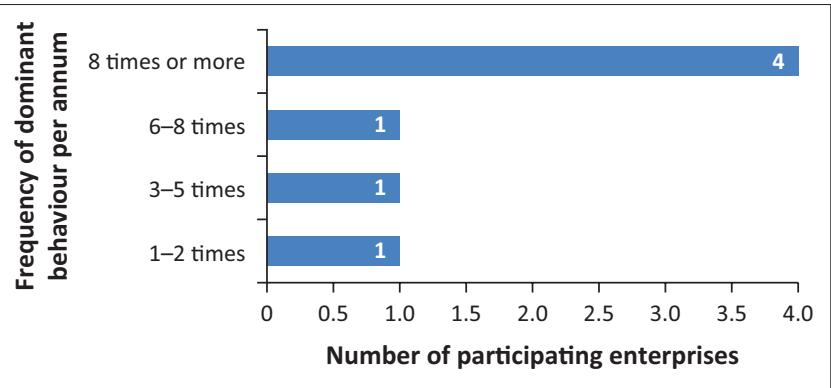

FIGURE 4: Frequency of dominant practices as experienced by participants.

uncertainty in regard to contract renewal as retailers had the option to cancel contracts and agreements at any time.' (Participant 2, medium-sized business owner, July 2018)

'Retailers demand discounts for prompt payment.' (Participant 4, micro business owner, July 2018)

An example provided by the participants of a penalty for late delivery was of $2 \%$ credit on value of outstanding goods exceeding 2 days of contractual lead time, thereafter $2 \%$ everyday two days up to a maximum of $10 \%$.

Five participants stressed that it is difficult to overcome dominant behaviour in contractual agreements owing to the SME suppliers' low bargaining power in the market. The supplier market for apparel is highly competitive and, thus, 'take it or leave it' scenarios are common. The lack of a supplier voice is also echoed in the reluctance of many suppliers to participate in the interviews. It can be concluded that for many SMEs, the fear of losing business is greater than the will to retaliate against large retailers.

The seven participants all stated that they had been affected by dominant behaviour but to different degrees. To determine the degree and to make an objective comparison, participants were asked to indicate on a 5-point Likert scale. One participant felt 'extremely' affected by dominant behaviour, another 'mostly' affected and three participants felt 'affected'. Only two participants felt 'marginally' affected by dominant behaviour. When asked in what way they had been affected, they indicated that the dominant practices largely impact the cash flow of the business. This directly relates to the identification of the most commonly used methods of dominance by retailers as identified by the participants, namely late payments and extended payment terms. One participant stated:

'Late payments have the biggest impact as it decreases the available cash flow in the business.' (Participant 2, mediumsized business owner, July 2018)

Late payment terms make it difficult to pay suppliers on time and decrease cash flow through the business.

Extended payment terms have a similar effect on the business, making it difficult to expand owing to a decrease in available cash flow. SMEs are more financially at risk as they do not have the same cash reserves that large enterprises possess. 


\section{Business risk resulting from dominant behaviour}

Four of the seven participants stated that dominant behaviour by retailers put their business at risk. Participants stated the following:

'Financially the impact for me as a small business owner is large as I cannot buy new material if I do not have a constant cash flow ... [and the] financial risk [was that they had] to borrow money from family members and take out a business loan from the bank.' (Participant 4, micro business owner, July 2018)

'Financial risk, loss of contracts. Price negotiation and in some cases had to stop supplying.' (Participant 5, small business owner, July 2018)

'Financial strain, threat of losing contract.' (Participant 6, small business owner, July 2018)

'Financial risk would be the biggest impact: the business has had to take out an overdraft and led from other businesses that are family owned to stay afloat and wait for payments.' (Participant 3, small business owner, July 2018)

Financial risk was most prevalent with loss of contracts and market share. Suppliers were often forced to apply for an overdraft or loan money from family members or banks. A participant added:

'Large retailers are stocking more of their own brands, therefore ordering less from the company and many others like it in the industry.' (Participant 5, small business owner, July 2018)

'Competition in the form of the retailer playing one supplier against another to decrease prices to an almost impossible cost for the business.' (Participant 3, small business owner, July 2018)

Supplying large apparel retailers has become a competitive risk as retailers prefer to stock their own brands thus adding pressure on suppliers to be more cost effective. There was evidence of legal risk as expenses and losses were incurred in the settling of disputes.

Participants stressed that continually decreasing their prices to remain competitive decreased their profit margin which in turn affected their operating ability. Year-on-year growth of SMEs was also affected as suppliers were forced to exit some markets owing to unrealistic expectations by retailers. One participant remarked:

'In some cases, the business recognised the dominance as good because if you can compete at a high level, you will maintain a large market share.' (Participant 3, small business owner, July 2018)

Another participant, who had previously worked for a major retailer, stated that whilst he recognised dominant behaviour, it had not negatively affected the business as he had established important relationships during his time as an employee at the retailer.

\section{Supply chain relationships with retailers}

The extent of time that a supplier and retailer have been in business with one another could play a vital role in determining the strength of such a relationship and the degree of dominance that develops. From a probing question as to the improvement of the supplier-byer relationship over the years, the answers varied. In most cases as the length of time increased, the level of dominance decreased, as relationships were formed and trust grew. An exception is the case of a specific retailer, for whom dominant behaviour increased with an increase in the length of the relationship. The participant noted that the retailer took advantage of the supplier's dependence and added stricter conditions for delivery and payment terms.

\section{Surviving the use of dominant practices by retailers}

In summary, all SME apparel suppliers interviewed concurred that some form of dominance was used by retailers with varying degrees. Of the list of 18 different retailers supplied by the participating enterprises, three displayed the greatest degree of dominant behaviour, of which the most common form of dominant behaviour was extended payment terms and late payments. It was found that the larger retailers displayed a greater degree of dominant behaviour than the smaller retailers.

Participants were asked to comment on their ability to counteract dominant behaviours. They commented as follows:

'Try best to negotiate ... [and] reduce customers (refuse some terms that cannot be met and do not supply those retailers).' (Participant 3, small business owner, July 2018)

'[We] had to exit some of the market places which decreased growth of the business over the past few years. [We] had to branch out into new markets to stay relevant. [We] had to ensure that complete orders were delivered and paid (no partial delivery). [We went] through lots of negotiating and offering favourable business terms.' (Participant 2, medium-sized business owner, July 2018)

'[We] had to become very effective with pricing strategies.' (Participant 7, medium-sized business owner, July 2018)

In summary, five of the seven participants stated that they were to some extent able to overcome these dominant behaviours by setting lower prices compared to competitors, keeping prices as regular as possible, operating on a smaller scale, selling directly to the public, keeping low stock levels, ensuring quick turnovers and negotiating improved business terms.

\section{Discussion}

The findings of this study are aligned with previous research indicating the presence of dominant behaviour by buyers in supply chains (Bala \& Kumar 2011; Barber 2011; Defee et al. 2009; Durocher-Yvon et al. 2019; Habib et al. 2015; Kampstra et al. 2006; Wang et al. 2008). Consistent with Talay et al. (2020), the results indicate that large buyers do dominate small suppliers. The enforcement of financial dominant behaviours on weaker members of the supply chain is consistent with that of Durocher-Yvon et al. (2019). The most common of these behaviours were late payments and longpayment terms. 
A study conducted by the Federation of Small Businesses indicated that $20 \%$ of small businesses in the United Kingdom are dominated by the businesses they supply (The Federation of Small Businesses 2018). Furthermore, Durocher-Yvon et al. (2019) and Schleper et al. (2017) indicate that globally most incidences of dominant behaviour occur in the retail industry. Digal (2015), Hingley (2005), Knox (2016) and Palpacuer et al. (2005) have all investigated dominant buyer behaviour in the retail sector. This study is consistent with prior research on the SME experience of dominant behaviour (Talay et al. 2020). Four out of seven respondents indicated that dominant behaviour occurred at least eight times a year.

Dominant behaviour by large and powerful retailers affected the cash flow of most SMEs that participated in this study. This left them vulnerable to business risks such as loss of contracts, loss of competitiveness and decreased profits, which is consistent with the findings of Kirkwood (2014). Von Broembsen (2017) found that egregious contractual terms by large retailers in South Africa increased the supplier's survival risk. Similarly, financial risk arising from a loss of contract or market share was tied to the survival rate of the supplier.

Consistent with the findings of Jarratt and Morrison (2003), the results indicate that the management of the relationship over a period of time increased the fairness in the relationship, especially regarding controlling behaviour. Some suppliers were willing to work with retailers to counteract dominant behaviour. Pursuing a collaborative strategy, even when not in a dominant position, is comparable to the findings of Talay et al. (2020).

This research has contributed to theory and practice by confirming that supply chain relationships should be examined in the specific context of dominant behaviour by one or more partners ensuring a more balanced perspective.

\section{Conclusion}

Supply chain dominance is a global phenomenon, and this research attempted to determine the extent and effect of supply chain dominance in South Africa, focusing on the apparel supply chain in Gauteng. After an intensive effort to find participants, it was possible to conduct in-depth interviews with seven SMEs. The extent of supply chain dominant behaviour can be extended to SMEs that refused to grant the researchers an interview, in fear of losing retail customers if they identified unfair business practices.

Firstly, the extent of dominant behaviour in relation to SMEs in the apparel retail supply chain in Gauteng was investigated. All seven participants with several years of experience in the apparel industry had faced dominant supply chain practices on a frequent basis. The three forms of supply chain dominance most commonly experienced by the participants are late payments, followed by long payment term and then discount for prompt payment. These one-sided adjustments to the payment structure have serious financial consequences for the SMEs, affecting their cash flow. From the interaction with participants, it seems that it is the larger and wellknown retailers that display supply chain dominant behaviours. As these well-known retailers have a large market share, SMEs want to have a continuous long-term relationship with them to secure a source of stable income. These participating SMEs do not have the negotiating power to confront the retail giants and consequently resort to cost-cutting measures to increase profit-margin.

\section{Management implications for small and medium-sized enterprises}

From the findings, it is only possible to alert all SMEs to the fact that supply chain dominance does occur, albeit to varying degrees. From the comments of the participating SMEs, it seems that supply chain bullying is something that SMEs would have to accommodate in their strategic planning. Although building good relationships with the retailers is essential, SMEs should focus on streamlining operations to allow for larger profit margins. Where possible, SMEs should endeavour to expand their customer base to reduce reliance on a few retail customers.

\section{Limitations}

The major limitation to the research conducted was the reluctance of the participants to be interviewed. This resulted from the fear of repercussions for participating in a research study that was investigating uncompetitive actions in the supply chain, in particular stemming from the SMEs' largest customers. They feared a breach in confidentiality and a loss of business supplying the large retailers. A loss of such a major customer would result in bankruptcy for some SMEs, and their fear is justified.

\section{Future research}

To overcome the fear of participation of SME suppliers, it would be necessary to shift the focus away from supply chain dominance onto a topic that would be less threatening. The focus could be on payment practices in the supply chain. From the responses to the carefully constructed questions, it should be possible to determine whether buyer dominance does occur and the extent of its occurrence.

\section{Acknowledgements}

We acknowledge D.D. Scott, K. Parag and K. McGillMcGowen for their valuable contribution and concerted effort in collecting the data for the manuscript and the preliminary discussion of the findings.

\section{Competing interests}

The authors declare that they have no financial or personal relationships that may have inappropriately influenced them in writing this research article. 


\section{Authors' contributions}

S.G.N. and E.S. contributed equally to the writing of this article.

\section{Funding information}

This research received no specific grant from any funding agency in the public, commercial or not-for-profit sectors.

\section{Data availability}

The authors confirm that the data supporting the findings of this study are available within the article.

\section{Disclaimer}

The views and opinions expressed in this article are those of the authors and do not necessarily reflect the official policy or position of any affiliated agency of the authors.

\section{References}

Ambrose, E., Marshall, D. \& Lynch, D., 2010, 'Buyer supplier perspectives on supply chain relationships', International Journal of Operations \& Production Management 30(12), 1269-1290. https://doi.org/10.1108/01443571011094262

Amed, I., Balchandani, A., Beltrami, M., Berg, A., Hedrich, S. \& Rölkens, F., 2019, What issues matter for brands and retailers most in the coming months, viewed 15 January 2021, from https://www.mckinsey.com/industries/retail/our-insights/ ten-trends-for-the-fashion-industry-to-watch-in-2019\#.

Arshinder, K., Kanda, A. \& Deshmukh, S.G., 2011, 'A review on supply chain coordination: Coordination mechanisms, managing uncertainty and research directions', in T.-M. Choi \& T.C.E. Cheng (eds.), Supply chain coordination under uncertainty, pp. 39-82, Springer, Berlin.

Bala, M. \& Kumar, D., 2011, 'Supply chain performance attributes for the fast moving consumer goods industry', Journal of Transport and Supply Chain Management 5(1), a19. https://doi.org/10.4102/jtscm.v5i1.19

Barber, E., 2011, Strategic approaches to domination in supply chains, InTech, United Kingdom.

Benton, W.C. \& Maloni, M., 2005, 'The influence of power driven buyer/seller relationships on supply chain satisfaction', Journal of Operations Management 23(1), 1-22. https://doi.org/10.1016/j.jom.2004.09.002

Bertram, R.F. \& Chi, T., 2018, 'A study of companies' business responses to fashion e-commerce's environmental impact', International Journal of Fashion Design Technology and Education 11(2), 254-264. https://doi.org/10.1080/17543266.20 17.1406541

Black, Z., 2020, 'Bullying' clothing companies are asking struggling suppliers for discounts, viewed 15 January 2021, from https://thenewdaily.com.au/finance/ consumer/2020/05/13/kmart-mosaic-coronavirus/.

Broembsen, M.V., 2017, Suppliers at a huge disadvantage when dealing with supermarkets, viewed 15 January 2021, from https://www.businesslive.co.za/bd/ opinion/2017-06-23-suppliers-at-a-huge-disadvantage-when-dealing-withsupermarkets/.

Bureau for Economic Research, 2016, The small, medium and micro enterprise sector of South Africa, BER, s.l. viewed n.d., from http://www.seda.org.za/publications/ publications/the $\% 20$ small, $\% 20$ medium $\% 20$ and $\% 20$ micro\%20nterprise $\% 20$ sector\%20of\%20south\%20africa\%20commissioned\%20by\%20seda.pdf

Cambero, F., 2020, Walmart Chile facing supplier suit over allegations it abused market dominance, viewed 15 January 2021, from https://www.reuters.com/ article/us-walmart-chile/walmart-chile-facing-supplier-suit-over-allegations-itabused-market-dominance-idUSKBN27E2GA.

Chakraborty, A., Mateen, A., Chatterjee, A.K. \& Haldar, N., 2018, 'Relative power in supply chains - Impact on channel efficiency \& contract design', Computers \& Industrial Engineering 122, 202-210. https://doi.org/10.1016/j.cie.2018.05.052

Chen, K. \& Zhuang, P., 2011, 'Disruption management for a dominant retailer with constant demand-stimulating service cost', Computers \& Industrial Engineering 61(4), 936-946. https://doi.org/10.1016/j.cie.2011.06.006

Chen, Z., 2003, 'Dominant retailers and the countervailing-power hypothesis', The RAND Journal of Economics 34(4), 612-625.

Cox, A., 1999, 'Power, value and supply chain management', Supply Chain Management: An International Journal 4, 167-175.

Cox, A., 2004, 'The art of the possible: Relationship management in power regimes and supply chains', Supply Chain Management: An International Journal 9(5) 346-356. https://doi.org/10.1108/13598540410560739
Cox, A., Watson, G., Lonsdale, C. \& Sanderson, J., 2004, 'Managing appropriately in power regimes: Relationship and performance management in 12 supply chain cases', Supply Chain Management: An International Journal 9(5), 357-371. https://doi.org/10.1108/13598540410560748

Creswell, J., 2014, Research design: Qualitative, quantitative and mixed methods designs, Sage, Thousand Oaks, CA.

Defee, C., Randall, W. \& Gibson, B., 2009, 'Roles and capabilities of the retail supply chain organization', Journal of Transportation Management 21(2), 31-48. https:// doi.org/10.22237/jotm/1254355440

Dekimpe, M.G., 2020, 'Retailing and retailing research in the age of big data analytics', International Journal of Research in Marketing 37(1), 3-14. https://do. org/10.1016/j.ijresmar.2019.09.001

Delberghe, C., 2016, Retailer brands: Serving consumers, SMES and innovation, EuroCommerce, European Union.

Department of Small Business Development, 2019, Revised schedule 1 of the nationa definition of small enterprise in South Africa, Department of Small Business Development, Government Printing Works, Pretoria.

Digal, L.N., 2015, 'Modern retail food sector in the Philippines: Dominance of large domestic retailers and their effects on the supply chain', The International Review of Retail, Distribution and Consumer Research 25(4), 407-430. https://doi.org/10. 1080/09593969.2015.1023214

Douglas, K., 2016, 'Are South African fashion retailers feeling pressure from global brands?', How we made it in Africa, viewed 15 January 2021, from https://www. howwemadeitinafrica.com/south-african-fashion-retailers-feeling-pressureglobal-brands/55703/.

Dukes, A.J., Geylani, T. \& Srinivasan, K., 2009, 'Strategic assortment reduction by a dominant retailer', Marketing Science 28(2), 309-319. https://doi.org/10.1287/ mksc.1080.0399

Durocher-Yvon, J.-M., Tappin, B., Goolam Nabee, S. \& Swanepoel, E., 2019, 'Relevance of supply chain dominance: A global perspective', Journal of Transport and Supply Chain Management 13(0), a455. https://doi.org/10.4102/jtscm.v13i0.455

Emmett, S. \& Crocker, B., 2006, The relationship-driven supply chain: Creating a culture of collaboration throughout the chain, Routledge, London.

Euromonitor International, 2020, Retailing in South Africa, Euromonitor International, London.

Flanders Investment \& Trade, 2016, South African retail fact sheet apparel, Flanders Investment \& Trade, Sandton.

Gordon, S., 2011, Retail bully boys must not protect themselves unfairly, viewed 15 January 2021, from https://www.ft.com/content/eb78f00c-f0d5-11e0-aec800144 feab49a.

Greenfield, R., 2011, Let's count all the ways Amazon's a big bully, viewed 17 January 2021, from https://www.theatlantic.com/business/archive/2011/12/lets-countall-ways-amazons-big-bully/333771/.

Guo, L., Hsu, S.-H., Holton, A. \& Jeong, S.H., 2012, 'A case study of the Foxconn suicides: An international perspective to framing the sweatshop issue', International Communication Gazette 74(5), 484-503. https://doi.org/10.1177/ 1748048512445155

Habib, F., Bastl, M. \& Pilbeam, C., 2015, 'Strategic responses to power dominance in buyer-supplier relationships: A weaker actor's perspective', International Journa of Physical Distribution \& Logistics Management 45(1/2), 182-203. https://doi. org/10.1108/IJPDLM-05-2013-0138

He, S., Hipel, K.W. \& Kilgour, D.M., 2014, 'A hierarchical approach to study supply chain conflicts between Airbus and Boeing', 2014 IEEE international conference on Systems, Man, and Cybernetics (SMC), San Diego, CA, Systems, Man and Cybernetics Society, 05-08 October 2014, pp. 1559-1564.

Hingley, M., Lindgreen, A. \& Grant, D.B., 2015, 'Intermediaries in power-laden retail supply chains: An opportunity to improve buyer-supplier relationships and collaboration', Industrial Marketing Management 50, 78-84. https://doi. org/10.1016/j.indmarman.2015.05.025

Hingley, M.K., 2005, 'Power to all our friends? Living with imbalance in supplierretailer relationships', Industrial Marketing Management 34(8), 848-858. https:// doi.org/10.1016/j.indmarman.2005.03.008

Jarratt, D. \& Morrison, M., 2003, 'Dependence and the application of power and control in major business relationships: A study of manufacturing and service firms in the business-to-business sector', Journal of Strategic Marketing 11(4), 235-253. https://doi.org/10.1080/0965254032000159054

Jerath, K., Hoch, S. \& Zhang, Z., 2007, The pursuit of retailing dominance: Market dominance, channel dominance or both?, Carnegie Mellon University, Pittsburgh, PA.

Kaira, Z. \& Rześny Cieplińska, J., 2019, 'Innovation strategies in SME's economic growth and job creation in economy', WSB Journal of Business and Finance 53(1), 167-173. https://doi.org/10.2478/wsbjbf-2019-0016

Kampstra, R.P., Ashayeri, J. \& Gattorna, J.L., 2006, 'Realities of supply chain collaboration', The International Journal of Logistics Management 17(3), 312-330. https://doi.org/10.1108/09574090610717509

Kew, J., 2020, South African retailers turn from China to source local clothes, viewed 15 January 2021, from https://www.moneyweb.co.za/news/companies-anddeals/south-african-retailers-turn-from-china-to-source-local-clothes/.

Khan, A., 2018, 'Managing risks under highly dependent supplier-producer relation in modern automotive industry', in I. Dovbischuk, G. Siestrup \& A. Tuma (eds.), machhaltige Impulse für Produktion und Logistikmanagement: Festschrift zum 60 . Geburtstag von Prof. Dr. Hans-Dietrich Haasis, Springer Fachmedien Wiesbaden, Geburtstag 
Kirkwood, J., 2014, 'Collusion to control a powerful customer: Amazon, e-books, and antitrust policy', SSRN Electronic Journal 69(1). https://doi.org/10.2139/ssrn. 2399575

Klemz, B.R., Boshoff, C. \& Mazibuko, N.-E., 2008, 'Fighting off the big guys: Comparing competitive retail services strategies in industrialized and developing world settings', Service Business 2, 127-145. https://doi.org/10.1007/s11628-007-0028-9

Knox, M., 2016, Supermarket monsters: The price of Coles and Woolworths' dominance, Black Inc. Redback, Victoria.

Kumar, R., Singh, R. \& Shankar, R., 2016, 'Study on collaboration and information sharing practices for SCM in Indian SME', International Journal of Busines Information Systems 22(4), 455. https://doi.org/10.1504/IJBIS.2016.077838

Lapko, Y. \& Trucco, P., 2018, 'Influence of power regimes on identification and mitigation of material criticality: The case of platinum group metals in the automotive sector', Resources Policy 59, 360-370. https://doi.org/10.1016/j. resourpol.2018.08.008

Layne, N., 2015, Wal-Mart puts the squeeze on suppliers to share its pain as earnings sag, viewed 15 January 2021, from https://www.reuters.com/article/us-walmart-suppliers-insight/wal-mart-puts-the-squeeze-on-suppliers-to-share-itspain-as-earnings-sag-idUSKCNOSDOCZ20151019.

Li, J., Sheng, Z. \& Liu, H., 2010, 'Multi-agent simulation for the dominant players' behavior in supply chains', Simulation Modelling Practice and Theory 18(6) behavior in supply chains', Simulation Modelling Practic
$850-859$. https://doi.org/10.1016/j.simpat.2010.02.001

Liedtke, S., 2019, SME sector 'critical' to growing South Africa's economy - Pityana, viewed 16 January 2021, from https://www.engineeringnews.co.za/article/smeviewed 16 Janua 2021, frition hithe-

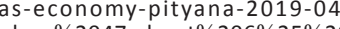
11\#: : :text=The $\% 20$ SME $\% 20$ sector $\% 20$ employs $\% 2047$, about $\% 206 \% 25 \% 20$ position,to $\% 20136 \% 20$ out $\% 20$ of $\% 20190$.

Lin, F., Ansell, J., Marshall, A. \& Ojiako, U., 2019, 'Managing and building B2B SME brands: An emerging market perspective', PSU Research Review 3(3), 191-214. brands: An emerging market perspective',
https://doi.org/10.1108/PRR-04-2019-0010

Manuel Xavier, J., Ferreira Moutinho, V. \& Carrizo Moreira, A., 2015, 'An empirical examination of performance in the clothing retailing industry: A case study', Journal of Retailing and Consumer Services 25, 96-105. https://doi.org/10.1016/j. jretconser.2015.04.002

Marketline, 2020a, Apparel retail in South Africa, Industry Profile MarketLine, London.

Marketline, 2020b, Global apparel retail, Industry Profile MarketLine, London.

Mccoll, J. \& Moore, C., 2013, 'Developing a value chain for fashion retailers: Activities for competitiveness', in H. Schramm-Klein (ed.) European retail research: 2012, Volume 26, Issue II, Springer Fachmedien Wiesbaden, Wiesbaden.

Munyimi, T.F. \& Chari, D.F., 2018, 'The role of buyer-supplier relationships in achieving economic sustainability in the private telecommunication sector in Zimbabwe', Cogent Business \& Management 5(1), 1540917. https://doi.org/10.1080/233119 Cogent Business \&
75.2018 .1540917

Neville, S., 2013, Laura Ashley boss dismisses accusations of bullying supplier, viewed 15 January 2021, from https://www.theguardian.com/business/2013/mar/28/ 15 January 2021, from https://www.theguard

Noémi, V., 2012, 'Members of a supply chain and their relationships', Applied Studies in Agribusiness and Commerce 6(5), 131-134. https://doi.org/10.19041/ APSTRACT/2012/5/21

Palpacuer, F., Gibbon, P. \& Thomsen, L., 2005, 'New challenges for developing country suppliers in global clothing chains: A comparative European perspective', World Development 33(3), 409-430. https://doi.org/10.1016/j.worlddev.2004.09.007

Parliamentary Committee Group, 2019, Department of Small Business Development 2019/20 annual performance plan, with minister \& deputy minister, viewed 15 January 2021, from https://pmg.org.za/committee-meeting/28475/.

Pepe, C., Musso, F. \& Risso, M., 2010, SME food suppliers versus large retailers: Perspectives in the international supply chains. McGraw-Hill, Milan.

Popović, V., Mihailović, B. \& Simonovic, Z., 2018, 'Modern food retail and unfair trading practices', Ekonomika poljoprivrede 65(4), 1499-1511. https://doi. org/10.5937/ekoPolj1804499P

Rahaman, M.M., Rau, P.R. \& Zaman, A.A., 2020, 'The effect of supply chain power on bank financing', Journal of Banking \& Finance 114, 105801. https://doi. org/10.1016/j.jbankfin.2020.105801

Ram, A., 2016, Tesco probe raises concerns that retailers dominate supply chain, viewed 15 January 2021, from https://www.ft.com/content/03c8b820-c5b3-11e5-808f8231 cd71622e.

Raven, B.H. \& French Jr., J.R.P., 1958, 'Group support, legitimate power, and social influence', Journal of Personality 26(3), 400-409. https://doi.org/10.1111/j.14676494.1958.tb01595.x
Research and Markets, 2019, The clothing industry in South Africa 2019, Research and Markets, Dublin.

Rogers, H. \& Fells, R., 2017, 'Successful buyer-supplier relationships: The role of negotiations', Journal of Strategic Contracting and Negotiation 3(3), 121-136. https://doi.org/10.1177/2055563618763037

Ryu, I., Soh, S. \& Koo, C., 2009, 'The role of partnership in supply chain performance', Industrial Management and Data Systems 109(4), 496-514. https://doi. org/10.1108/02635570910948632

Saunders, M.N.K., Lewis, P. \& Thornhill, A., 2019, Research methods for business students, Harlow, New York, NY.

Schleper, M.C., Blome, C. \& Wuttke, D.A., 2017, 'The dark side of buyer power: Supplier exploitation and the role of ethical climates', Journal of Business Ethics 140, 97-114. https://doi.org/10.1007/s10551-015-2681-6

Schlossberg, M., 2016, The top retailer in the world has a dirty little secret - and it's spiraling out of control, viewed 17 January 2021, from https://www. businessinsider.com/zara-accused-of-copying-artists-and-designers-2016 7 ? international=true $\& r=U S \& I R=T$.

Seppenwoolde, J.J., 2019, 'The strategic options to counteract power dominance and the opportunities to increase attractiveness by delivering higher value to partners in buyer-seller relationships: A case study to the possibilities of a weaker actor in the transportation sector', Master of Science (M.Sc.), Business Administration, Purchasing \& Supply Management, University of Twente.

Skeete, J.-P., 2019, 'Concentration of power: A UK case study examining the dominance of incumbent automakers and suppliers in automotive sociotechnical transitions', Global Transitions 1, 93-103. https://doi.org/10.1016/j. glt.2019.06.001

Small Business Institute, 2018, The number of formal micro, small \& medium businesses in South Africa. Small Business Institute, Sandton.

Talay, C., Oxborrow, L. \& Brindley, C., 2020, 'How small suppliers deal with the buyer power in asymmetric relationships within the sustainable fashion supply chain', Journal of Business Research 117, 604-614. https://doi.org/10.1016/j. jbusres.2018.08.034

Tang, C., Zimmerman, J. \& Nelson, J., 2009, 'Managing new product development and supply chain risks: The Boeing 787 case', Supply Chain Forum 10(2), 74-86. https://doi.org/10.1080/16258312.2009.11517219

The Federation of Small Businesses, 2018, Chain reaction: Improving the supply chain experience for small firms, viewed $n$.d., from https://www.fsb.org.uk/resource-
report/chain-reaction-improving-the-supply-chain-experience-for-small-firms. report/ch
html.

Tsao, Y.-C., 2011, 'Managing a retail-competition distribution channel with incentive policies', Applied Mathematical Modelling 35(9), 4140-4148. https://doi. org/10.1016/j.apm.2011.02.034

Vlachos, I.P. \& Bourlakis, M., 2006, 'Supply chain collaboration between retailers and manufacturers: Do they trust each other?', Supply Chain Forum 7(1), 70-80. https://doi.org/10.1080/16258312.2006.11517159

Von Broembsen, M., 2017, 'You can't bite the hand that feeds you': Contracts between SME suppliers and the large supermarkets, viewed 17 January 2021, from http:// www.econ $3 \times 3$.org/article $/ \% \mathrm{E} 2 \% 80 \% 98$ you-can $\% \mathrm{E} 2 \% 80 \% 99 \mathrm{t}$-bite-hand-feeds-

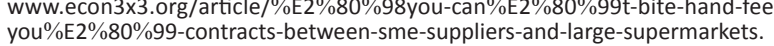

Wang, J.-C., Lau, H.-S. \& Lau, A.H.L., 2008, 'How a retailer should manipulate a dominant manufacturer's perception of market and cost parameters', International Journal of Production Economics 116(1), 43-60. https://doi. org/10.1016/j.ijpe.2008.06.007

Watchravesringkan, K., Karpova, E., Nelson Hodges, N. \& Copeland, R., 2010, 'The competitive position of Thailand's apparel industry: Challenges and opportunities for globalization', Journal of Fashion Marketing and Management 14(4), 576-597. for globalization', Journal of Fashion Marketing
https://doi.org/10.1108/13612021011081751

Whipple Judith, M. \& Russell, D., 2007, 'Building supply chain collaboration: A typology of collaborative approaches', The International Journal of Logistics Management 18(2), 174-196. https://doi.org/10.1108/09574090710816922

Wilhelm, M. \& Sydow, J., 2018, 'Managing coopetition in supplier networks - A paradox perspective', Journal of Supply Chain Management 54(3), 22-41. https:// doi.org/10.1111/jscm.12167

Xue, W., Caliskan Demirag, O. \& Niu, B., 2014, 'Supply chain performance and consumer surplus under alternative structures of channel dominance', European Journal of Operational Research 239(1), 130-145. https://doi.org/10.1016/j. ejor.2014.04.044

Young, I., 2020, Is Amazon bullying its suppliers?, viewed 17 January 2021, from https://www.etftrends.com/disruptive-technology-channel/is-amazon-bullyingits-suppliers/. 